Review

\title{
Fluorescence Microscopy Methods for the Analysis and Characterization of Lignin
}

\author{
Agustín Maceda $^{1}\left(\mathbb{D}\right.$ and Teresa Terrazas ${ }^{2, *(D)}$ \\ 1 Laboratorio Nacional de Investigación y Servicio Agroalimentario y Forestal, \\ Universidad Autónoma Chapingo, Texcoco 56230, Mexico; biologoagustin@hotmail.com \\ 2 Instituto de Biología, Universidad Nacional Autónoma de México, Mexico City 09230, Mexico \\ * Correspondence: tterrazas@ib.unam.mx; Tel.: +52-555622-9116
}

check for updates

Citation: Maceda, A.; Terrazas, T. Fluorescence Microscopy Methods for the Analysis and Characterization of Lignin. Polymers 2022, 14, 961. https: / / doi.org/10.3390/ polym14050961

Academic Editors: Oihana Gordobil, Stefan Beisl and René Herrera Díaz

Received: 1 February 2022

Accepted: 20 February 2022

Published: 28 February 2022

Publisher's Note: MDPI stays neutral with regard to jurisdictional claims in published maps and institutional affiliations.

Copyright: (C) 2022 by the authors. Licensee MDPI, Basel, Switzerland. This article is an open access article distributed under the terms and conditions of the Creative Commons Attribution (CC BY) license (https:// creativecommons.org/licenses/by/ $4.0 /)$.

\begin{abstract}
Lignin is one of the most studied and analyzed materials due to its importance in cell structure and in lignocellulosic biomass. Because lignin exhibits autofluorescence, methods have been developed that allow it to be analyzed and characterized directly in plant tissue and in samples of lignocellulose fibers. Compared to destructive and costly analytical techniques, fluorescence microscopy presents suitable alternatives for the analysis of lignin autofluorescence. Therefore, this review article analyzes the different methods that exist and that have focused specifically on the study of lignin because with the revised methods, lignin is characterized efficiently and in a short time. The existing qualitative methods are Epifluorescence and Confocal Laser Scanning Microscopy; however, other semi-qualitative methods have been developed that allow fluorescence measurements and to quantify the differences in the structural composition of lignin. The methods are fluorescence lifetime spectroscopy, two-photon microscopy, Föster resonance energy transfer, fluorescence recovery after photobleaching, total internal reflection fluorescence, and stimulated emission depletion. With these methods, it is possible to analyze the transport and polymerization of lignin monomers, distribution of lignin of the syringyl or guaiacyl type in the tissues of various plant species, and changes in the degradation of wood by pulping and biopulping treatments as well as identify the purity of cellulose nanofibers though lignocellulosic biomass.
\end{abstract}

Keywords: fluorescence microscopy; lignin; epifluorescence; confocal laser scanning microscopy; fluorescence analytical methods

\section{Introduction}

Lignin is one of the main components of the plant cell wall, as it provides structural rigidity to withstand differences in water pressure in vascular tissue [1]; in addition, lignin accumulates in specialized cells for support and storage, such as fibers, sclerenchyma, and parenchyma [2,3], and in the epidermis and cortex in conjunction with suberin and cutin [4]. Cellulose and hemicelluloses are part of the cell wall. Cellulose is the principal component with an accumulation of 40-44\% [5], mainly in the form of fibrils packed in crystalline or amorphous form; the higher the percentage of crystalline cellulose, the greater the hardness of the cellulose [6]. The accumulation of hemicelluloses in the cell wall is $15-32 \%$, and its main function is to bind cellulose with lignin; however, hemicellulose are more susceptible to being degraded by the attack of pathogenic fungi [5]. In contrast, lignin is more resistant to pathogens attack and accumulates in the cell wall between 18-35\% [5]. Lignin in the cell wall and in the lignocellulosic biomass is a limiting factor in the use of plant biomass because lignin is the restrictive barrier for the penetration of cellulase enzymes used for the degradation of cellulose [7,8]; therefore, lignin is primarily responsible for the recalcitrance of lignocellulose $[9,10]$.

The study of the composition of the cell wall of tree and herbaceous species is due to the potential for use in the paper industry [11,12] and biofuels $[13,14]$. Currently, there 
are standardized analytical techniques to characterize the composition of the cell wall, from methods to quantify the percentages of each cell component, such as the TAPPI standards [15], to specialized methods as chromatography, nuclear magnetic resonance, and spectroscopy to analyze and characterize the structural monomers of each lignocellulosic component [16].

Analyzing the structure of lignin in plant tissues and biomass is important because it provides information on the quality of cellulosic materials by identifying the presence of lignin in cellulose nanofibers, which affects the quality of production [17], such as in the identification of potential use of lignin from biofuels to its use as lignin nanoparticles [18,19]. In addition, based on the percentage of lignin present in the biomass, the potential for degradation of celluloses and hemicelluloses for fermentation and biofuel production can be identified [7]; and finally, the chemical composition of lignin allows identifying the possibility of hydrolyzing and using lignin for the production of biofuels [20]. The presence of greater amounts of syringyl (S) than guaiacyl $(G)$ in the lignin structure is one of the key factors for the identification of species susceptible to degradation by pulping, hydrolysis, or enzymes [21]. Syringyl-rich lignin has less condensation, less complex structure, smaller pore size, and higher $\beta$-ether content $[22,23]$, while $G$ monomers are linked by $\beta-5,5-5$ and $\beta-\beta$ bonds, which are more resistant to degradation [24].

The presence of autofluorescent monomeric structures in lignin is used in different fluorescence microscopy techniques to qualitatively and semi-qualitatively analyze plant cell walls and lignocellulosic biomass. The main advantage of fluorescence microscopy methods is the possibility of observing and analyzing the samples without the need to carry out a staining method in addition to the fact that it is not necessary to degrade or modify the samples as in other analytical methods [25]. There are several methods of fluorescence microscopy to analyze the structural components of plant tissues, living cells, and protein binding. However, the objective of this review is to identify and describe only the fluorescence microscopy methods used for the analysis and characterization of lignin from its polymerization, structure, and degradation to pulping and biopulping of lignocellulosic biomass.

\section{Structure and Autofluorescence of Lignin}

Lignin is a heteropolymer composed of three main monomers, namely $p$-coumaryl, coniferyl, and sinapyl alcohol [26]; once synthesized in the lignin molecule, the name of the monomers are $p$-hydroxyphenyl $(\mathrm{H})$, guaiacyl $(\mathrm{G})$, and syringyl $(\mathrm{S})$, respectively (Figure 1) [27]. However, another type of monomer present in lignin, caffeyl alcohol, has recently been discovered, mainly in the seed coat [28]. Lignin monomers are joined primarily by ether and carbon-carbon bonds, forming the guaiacylglycerol- $\beta$ aryl ether, phenylcoumarans, diarylpropane, resinol, biphenyl, and diphenyl ether structures [22]. The major bond in lignin is $\beta-\mathrm{O}-4$, which predominates in syringyl-rich lignin, while lignin with higher guaiacyl content has $\beta-5, \beta-1, \beta-\beta, 5-5$, and $5-\mathrm{O}-4$ bonds [29]. The presence of S-type or G-type lignin is important because the structure of the lignin varies in its conformation. Generally, S-type lignin predominantly has linear chains with fewer cross-links than G-rich lignin due to the fact that lignin $S$ has methoxylated groups, which block the C-5 position of the syringyl units, resulting in few highly stable 5-5 and $\beta-5$ bonds [21].

One of the properties of lignin is the presence of autofluorescence generated due to the presence of fluorophores in the lignin structure. Fluorophores are molecules that have the ability to absorb energy at a certain excitation wavelength that causes an excited electronic singlet state; during this short period (few nanoseconds), electron undergoes energy dissipation that is emitted in the form of light when the fluorophore returns to the ground state with a longer emission wavelength [30]. For each photon absorbed, there is a photon emitted, so the intensity of the fluorescence emission is directly proportional to the intensity of excitation, which, over time, causes the photo destruction of the fluorophore (photobleaching). To minimize the photodamage, it is necessary to reduce the exposure time and intensity, prepare the samples, and mount them with anti-quenches/fading agents [31]. 
A)

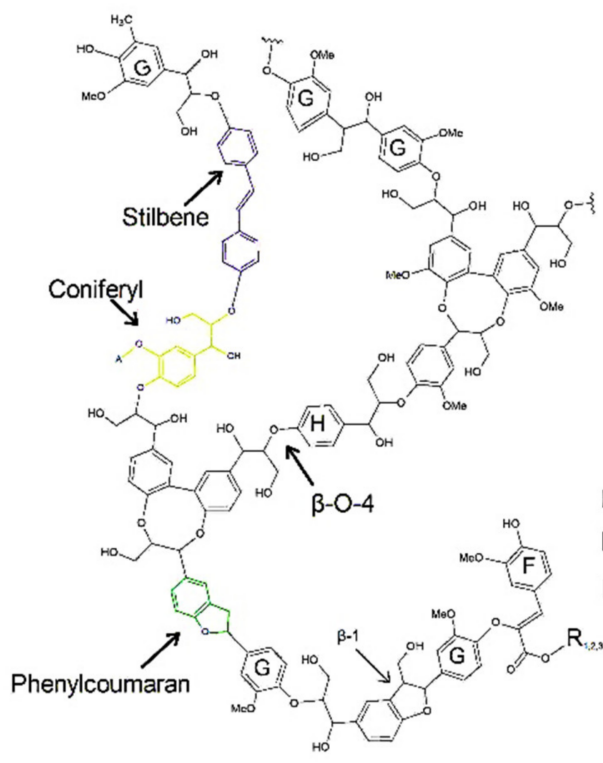

B)

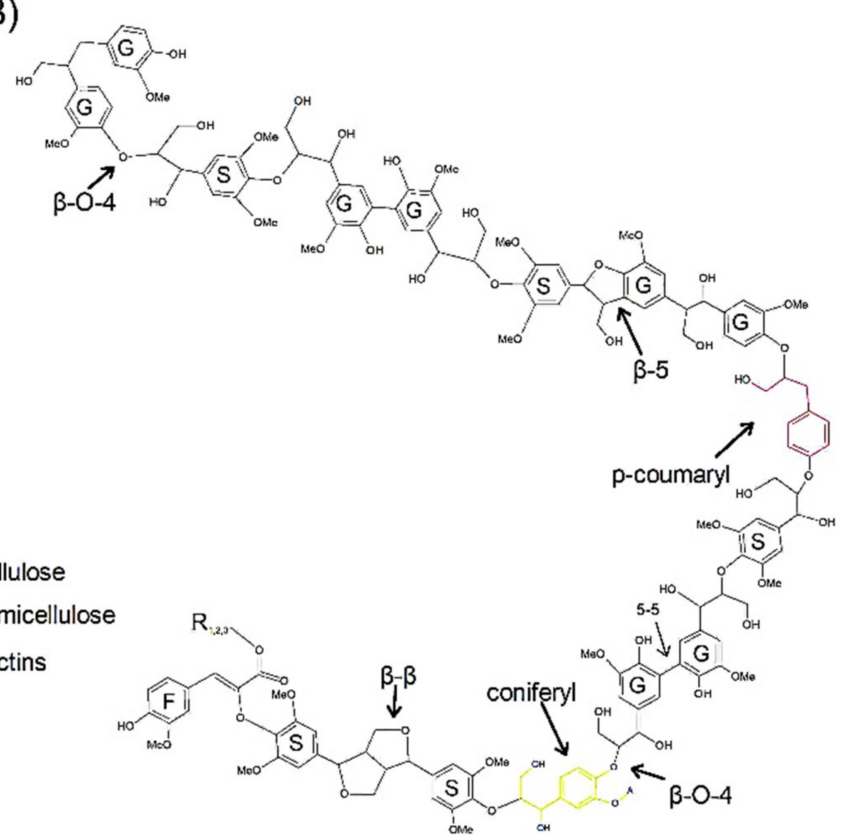

Figure 1. Molecular structure of lignin. (A) G-type lignin with the presence of fluorophores. (B) S-type lignin with the presence of fluorophores. F, ferulates; $\mathrm{H}$, $p$-hydroxyphenyl; $\mathrm{G}$, guaiacyl; S, syringyl.

For lignin, phenylcoumarans and stilbenes have been identified as the main chromophores [32] (Figure 1) although coniferyl alcohol, biphenyl [33], and to dibenzodioxocins [34] are also considered as lignin chromophores. Fluorescence emission is mainly due to benzene rings present in all lignin monomers. The presence of different side chains on the benzene ring and substitutions at various positions on the ring or side chain are what produce variations in the emission of fluorophores [35]. The blue tones of lignin are due to the grouping of carbonyl groups and the restriction of intramolecular rotation [36]. Therefore, different types of lignin can be identified based on the bands of the fluorescence spectra and also on the shades that are observed by fluorescence microscopy [37]. The lifetime of fluorescence is lower in fluorophores bound to lignin due to the fact that lignin structure presents random and chaotic bonds as well as branches compared to fluorophores bound to other structural components, such as cellulose [38]. In addition, the intensity of fluorescence varies based on $\mathrm{pH}$; the more alkaline $(\mathrm{pH} 9)$, the greater the intensity if visible light is used, while for UV excitation, there is no change in intensity [39].

Lignin excitation ranges are given with UV and visible light [40], the first with an emission in bluish tones and the second with an emission that is observed in the spectrum of visible light and includes reddish tones [41]. Because lignin fluorescence spans a broad excitation and emission spectrum, fluorescence lignin has been used for structural characterization within plant tissues, and lignocellulose biomass residues [42], due to degradation treatments, such as high temperatures and application of acids or enzymes, cause the lignin autofluorescence to decrease due to the breaking of the $\beta$-aryl-ether bonds so that the re-condensed lignin becomes a dense polymer into electrons, generating new, uncharacterized bonds [43].

Most fluorescence microscopy techniques take advantage of lignin autofluorescence to characterize and analyze lignin. However, biologically active monolignol analogs can also be synthesized with fluorophores, such as dimethyl-aminocoumarin (DMAC) and nitrobenzofuran (NDB), which bind to coniferyl alcohol monomers and that allow to identify the interactions between proteins and monolignols during the process of transport of monomers through the cytoplasm for their polymerization in the cell wall [44]. 


\section{Fluorescence Microscopy Methods}

Brightfield microscopy is the predecessor of fluorescence microscopy since for the analysis of lignin in plant tissues, methods such as safranin-fast green staining are used for the detection of lignified and non-lignified vascular tissue; the first will be observed in reddish tones, while the second will have greenish tones $[45,46]$. With the Mäule stain, it is possible to distinguish between lignin $S$ and lignin $G$ since the former has a red hue, while the latter has brown tones. Another method used to detect the presence of lignin is that of fluoroglucinol (Wiesner stain), which binds with the terminal 4-O bonds of $p$-hydroxy-cinnamaldehydes and $p$-hydroxy-benzaldehydes [47-49]. In addition, with tetramethylbenzidine (TMB), the activity of peroxidases is detected, which are key for the polymerization of lignin in the plant cell wall $[49,50]$.

In the case of fluorescence microscopy, there are several methods for lignin analysis, such as those used to obtain qualitative images: epifluorescence microscopy (Epi) and confocal laser scanning microscopy (CLSM). In addition, there are methods that allow semi-quantitative analysis, such as fluorescence lifetime imaging microscopy (FLIM), total internal fluorescence reflection (TIRF), fluorescence recovery after photobleaching (FRAP), Föster resonance energy transfer (FRET), microscopy of two-photon excitation (TPM), and simulated emission depletion (STED). Various dyes can be used to stain lignified tissues, such as acriflavine, safranin, and berberine sulfate [51-53], which preserve the emission of fluorescence for longer and avoid photobleaching of the sample since prolonged exposure to excitation by UV, white light, or laser can cause the fluorochromes to lose the ability to emit fluorescence [54]. When preparing the samples, the medium in which they are mounted and the $\mathrm{pH}$ must be considered since this can alter the intensity of fluorescence [39]. All fluorescence microscopy techniques provide valuable information on their own although they can complement each other or in conjunction with other analytical techniques, such as spectroscopy or chromatography.

A characteristic that the different techniques share is that they work at similar wavelengths both to excite the sample and to detect their fluorescence. In general, the range goes from 400 to $640 \mathrm{~nm}$. However, some methods, such as excitation, use UV ranges from $300 \mathrm{~nm}$ of excitation, while some lasers reach up to $820 \mathrm{~nm}$ of excitation [55]. For each technique, the power of the lasers or lamps and the type of filter cube that discriminates the wavelength that is emitted or detected vary.

Based on the intensity and wavelength in which the compounds are detected, whether in the blue, green, or red channel, some of the structural components present in the samples can be identified. In the case of lignin, the range in which fluorophores emit fluorescence is wide, so their presence can be detected in different channels [40] depending on the wavelength in which fluorophores are excited and detected in addition to the treatments or dyes that the sample receives, so the detection value can vary based on the method used [55].

\subsection{Wield-Field Fluorescence or Epifluorescence (Epi)}

Epi involves the simultaneous illumination and detection of the entire field of view with low doses of photons and the rapid acquisition of the image to avoid photobleaching. However, the main disadvantage is that Epi collects quite out-of- focus light (Figure 2), so a deconvolution procedure can be applied to the image to reduce the amount of out-of-focus light and obtain a better-quality image [56]. With Epi, is possible to analyze anatomical samples of plants with different thicknesses. Taking the image depends more on the preparation of the tissue than on its thickness, so an adequate preparation technique must be carried out both to minimize eliminate the autofluorescence of unwanted compounds as well as to highlighting the elements to be analyzed [57]. 


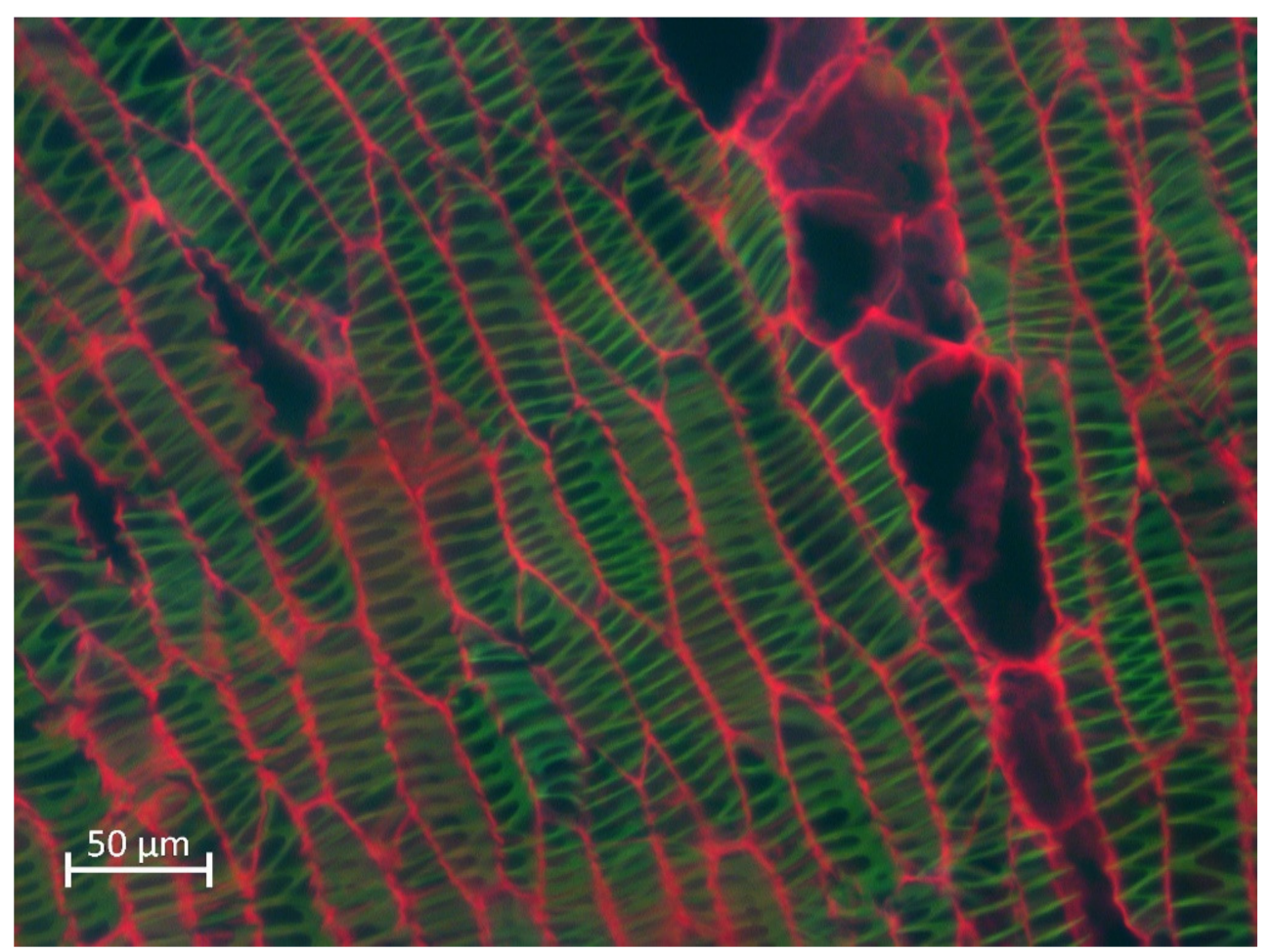

Figure 2. Epifluorescence image from a Lophocereus marginatus secondary xylem stained with safraninfast green, excited at $365 \mathrm{~nm}$ (blue), $470 \mathrm{~nm}$ (green), and $546 \mathrm{~nm}$ (red) at the same time. Scale bar: $20 \mu \mathrm{m}$. Image taken from personal file.

For the study of lignin, with Epi, lignin is detected by autofluorescence, so the distribution of lignin in phloem fibers of species important in the fiber industry can be analyzed [58]. Moreover, Epi detects differences in the percentage of lignin present in the plant tissue due to the intensity of fluorescence [39]. In addition, analyses of the quality of the wood can be carried out [59] to detect changes in the structure of lignified wood after thermal treatments [60].

Furthermore, with Epi, observations of stained samples are made. For example, with the Mäule procedure, analyses can be carried out that allow identifying differences in the composition of lignin based on the presence of syringyl or guaiacyl monomers [61]. With safranin-fast green staining, shade differences in the secondary xylem of various cacti species are detected due to the presence of lignin-rich S or G monomers [62]. Based on different types of dyes, such as Congo red or calcoflour, it is possible to make observations and take images of cellulosic structures and, in combination with lignin autofluorescence, determine the distribution of lignin in different timber species [57]. In addition, staining with safranin alone identifies the distribution of lignin [63], such as effects on degradation of lignified walls through brown-rot fungi attack [64].

\subsection{Confocal Laser Scanning Microscopy (CLSM)}

Similar to Epi, CLSM uses a focused laser at a defined point and at a specific depth and performs a transverse and axial scan to collect all the emitted fluorescence information by a point detector consisting of a pinhole. The pinhole eliminates most of the light outside the focal plane, so better-quality images can be obtained compared to Epi [65] (Figure 3). 


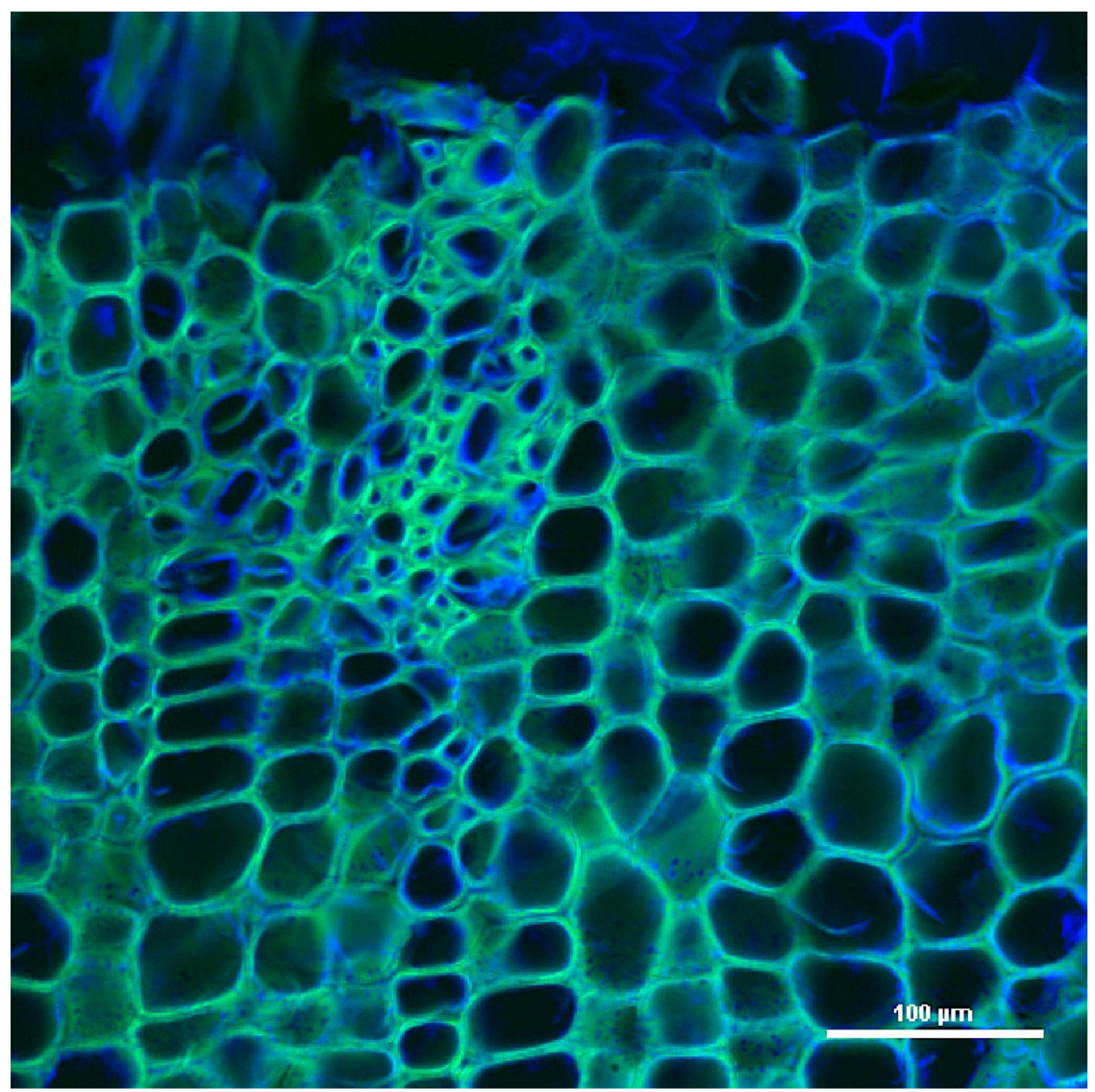

Figure 3. CLSM image from Cylindropuntia imbricata secondary xylem stained with safranin-fast green, excited at $405 \mathrm{~nm}$ (blue) and $488 \mathrm{~nm}$ (green) at the same time. Scale bar: $100 \mu \mathrm{m}$. Image taken from personal file.

The use of this method precedes and is the basis of other techniques because the image is first taken of the area to be analyzed, and later, analyses are carried out with techniques such as FRET [66,67]. CLSM is used in the observation of autofluorescence of plant tissues to calculate the relative amount of lignin present in the plant tissue of Arabidopsis thaliana $[68,69]$ and characterize and identify the distribution of lignin in compression and in normal wood of Pinus radiata [70]. New staining methods can also be tested to detect the quality of lignocellulosic biomass [71]; determine optimal tissue $\mathrm{pH}$ conditions to enhance lignin fluorescence emission [39]; analyze the changes in the structure of healthy, chlorotic, and degraded pine leaves [41]; and study the changes due to degradation of wood two thousand years old with respect to current wood [72]. Fluorescence through dyes, such as Congo red or fluorol yellow, in conjunction with lignin autofluorescence is also used to identify differences in the distribution of lignin in plant tissues of different species [57]. These differences in distribution can also be detected by using dyes for lignin [73], such as basic fuchsin [74] or safranin [53].

On the other hand, CLSM is a suitable method to verify the purity of lignin-free cellulose nanofibers [75]. In addition, CLSM is used to analyze biopulping procedures with lignin-degrading fungi [76], study the effectiveness of pretreatments for the degradation of recalcitrant biomass [77,78], and investigate the effectiveness of lignin-degrading peroxidases whose importance lies in the fact that they can be used for the purification of cellulose and the use of lignin residues $[79,80]$. CLSM is also used to test the efficiency of fluorescent synthetic monolignols that serve to identify the transport and polymerization in the cell wall of lignin in Arabidopsis [81-84], Pinus radiata [85], and Linum usitatissmum [86]; determine the polymerization of lignin with laccases [87]; and obtain the distribution of lignin in plant tissues [88]. 


\subsection{Fluorescence Lifetime Spectroscopy (FLIM)}

FLIM is a technique that makes it possible to identify the time that elapses between the excitation of the fluorophore, the emission of fluorescence, and its decay, which is measured in picoseconds or nanoseconds, and values obtained can be statistically analyzed [89]. However, FLIM analysis can only be used to infer the chemical changes in the sample but does not give information on what causes the changes, which may even be due to changes in the environment, such as $\mathrm{pH}$ [90]. FLIM measurement is done by single photon or multiple photons [40]; the latter has the ability to analyze up to $80 \mu \mathrm{m}$ deep, but unfortunately, with multiple photons, the cellular structure of the samples can be damaged. However, FLIM can be sensitive to various internal factors, such as the structure of the fluorophore, and external factors, such as temperature, polarity, and the presence of fluorescence quenchers [91]. The fluorescence lifetime of loosely packed lignin is on average $4 \mathrm{~ns}$ and is associated with secondary walls, while densely packed lignin has a shorter lifetime, between 0.5 to $1.0 \mathrm{~ns}$, so the difference in fluorescence lifetime of the analyzed samples provides relevant information about the type of lignin being analyzed [25].

With FLIM, the lignin fluorescence and the monomeric structures of lignin are detected since differences have been detected in the emission time and intensity of fluorescence due to the presence of different structural monomers when combining FLIM analysis with techniques such as spectroscopy Raman [90]. In addition, by combining CLSM to detect the intensity of fluorescence emission, in conjunction with FLIM, the distribution of different fluorophores with different lifetimes can be observed directly in plant tissues, which allows identifying variations in the composition of compression wood and normal wood [89].

Another analysis that can be performed is the detection of changes in the structural composition of lignin in samples treated with $\mathrm{H}_{2} \mathrm{SO}_{4}$ and $\mathrm{NaOH}$, for which changes in the fluorescence decay time are observed between untreated fibers with respect to the treated fibers [92]. These differences are also observed in samples treated by hydrolysis [93]. Therefore, some authors suggest that with this technique the saccharification rate can be efficiently calculated by means of hydrolysis, acid, and enzyme treatments without resorting to costly analytical methods [43]. On the other hand, using FLIM makes it possible to detect the efficacy of fungal degradation by comparing autofluorescence lifetimes between healthy and infected wood [94]. FLIM is also a suitable method to identify the purity of cellulose nanofibers by determining the absence or presence of lignin [38].

Some authors use FLIM to identify species, such as walnut, beech, spruce, and maple, through the differences in the lifetime of the fluorescence without the need for destructive procedures [95]. Escamez et al. [96] proposed that with FLIM, it is possible to obtain information on the $S / G$ ratio by directly analyzing the vascular tissue of the plants because differences were obtained in the fluorescence lifetimes of the vascular tissue of Arabidopsis thaliana based on the distribution of S and G [69].

A variant of FLIM is fluorescence spectral and lifetime measurement (SLiM), proposed by Terryn et al. to analyze the interaction between lignin-degrading enzymes and lignocellulose directly in plant tissues [97]. The difference with respect to FLIM is that it obtains the fluorescence lifetime and the CLSM image in a single wavelength range, with SLiM the range from $455 \mathrm{~nm}$ to $655 \mathrm{~nm}$ divided into 16 spectral channels so that both the images as the fluorescence lifetime are obtained for each channel. Subsequently, the lifetime fluorescence of each spectral channel is plotted, and the differences can be observed and compared specifically for each spectral.

\subsection{Two-Photon Microscopy (TPM)}

With this technique, thick samples are analyzed, so 3D images can be generated. However, unlike the confocal microscope, there is no photobleaching or phototoxicity above or below the plane in focus, which is why TPM has been used to characterize lignocellulose biomass samples [92]. TPM uses a double excitation by means of two photons simultaneously (Figure 4). Each photon has half the energy of the single-photon excitation event, so the energy of a photon is inversely proportional to its wavelength. In 
a two-photon excitation, the photons must have a wavelength approximately twice the wavelength of the photons needed to achieve an equivalent transition under one photon exposure. Therefore, if a fluorophore is excited at $400 \mathrm{~nm}$ under conventional excitation, fluorophore must be excited by two simultaneous photons at $800 \mathrm{~nm}$; thus, the fluorescence emission after double-photon excitation is similar to that obtained with a normal excitation of a photon [98].

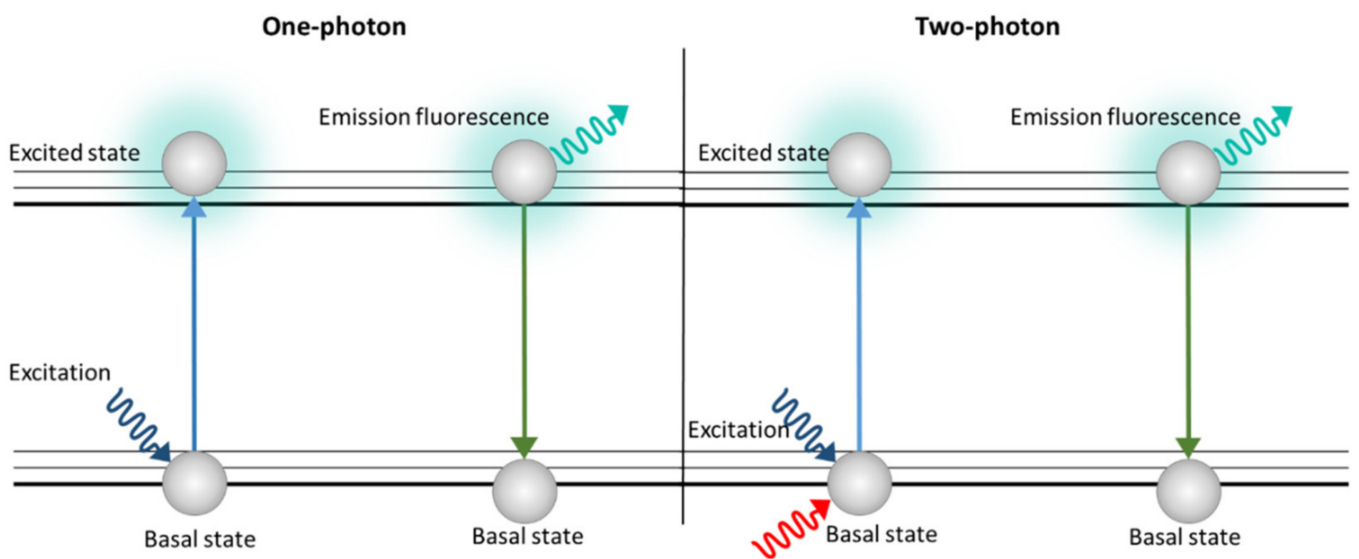

Figure 4. Schematic image of excitation with one photon (Epi, CLSM) and two photons (TPM).

This method is used to analyze autofluorescent and non-fluorescent samples, such as cellulose, since it is based on the signal generated by second-harmonic generation [99], without the need for staining [100]. This type of microscopy has been used to analyze the structural morphology of sugarcane bagasse before and after a hydrolysis and bleaching treatment because when penetrating the sample, better-quality details of the structure are obtained compared to confocal microscopy [93]. Similarly, the recalcitrant structures of lignin were identified in samples treated with enzymatic hydrolysis [55]; therefore, TPM is an efficient method to calculate the saccharification rate of lignocellulosic biomass by detecting changes in fluorescence emission [43]. On the other hand, TPM allows to identify structural changes in the wood coming from musical instruments of different ages [101] and serves to structurally analyze chitosan-lignin composite films [102].

\subsection{Förster Resonance Energy Transfer (FRET)}

This method consists of measuring the molecular interaction between two fluorophores by superimposing the emission and excitation spectra [103]. The process occurs when a donor fluorophore and an acceptor fluorophore are within $10 \mathrm{~nm}$, making it possible for a non-radiative transfer of excitation energy from donor to acceptor to occur [31]. When the distance between donor and acceptor increases, the efficiency of FRET decreases to the sixth power of the distance [97]. Measurement with FRET occurs by determining the changes in fluorescence intensity of the donor and acceptor or by the change in fluorescence over the lifetime of the donor in the presence or absence of the acceptor [31,40].

For the study of lignin, FRET uses the autofluorescence of lignin with the presence of a dye that generates fluorescence, and such is the case of lignin and the dye Rhodamine, where lignin is the donor and Rhodamine the receptor [40,97]. FRET can also be complemented with FLIM by measuring the fluorescence lifetime of the donor alone and of the donor in the presence of the acceptor so that a quantification of the efficiency of FRET and the distance between the donor and the acceptor can be made regardless of fluorophore concentration [31].

FRET has been used to determine the rate of saccharification of species with potential use [25]; in addition to that, FRET has allowed to determine the route of transport and polymerization of lignin in the cell wall [44] and the inhibition of peroxidase and oxidase enzymes due to their association with lignin nanoparticles [66]. On the other hand, FRET 
has been used as a basis for other methods, such as FRAP, TPM, and the SFLiM variant for the analysis of enzymatic interaction with lignin [103], or in conjunction with CLSM for the detection of nanostructural interactions between additives, such as polyethylene glycol (PEG), for the detection of recalcitrant lignin [67].

\subsection{Fluorescence Recovery after Photobleaching (FRAP)}

FRAP consists of three steps: The first is to mark a region of interest (ROI) in the sample and record the fluorescence intensity prior to photobleaching; then, the ROI is photobleached with a high-power laser beam so that the fluorophores in ROIs are destroyed and irreversibly stop fluorescing (Figure 5). Subsequently, the area around the fluorescent molecules that can freely distribute in the ROI increases, and thus, the ROI fluorescence increases so that the fluorescence recovery reaches a plateau. The scanning fraction that is exchanged between the unbleached area and the bleached area is called the mobile fraction, while the fraction that cannot be exchanged is called the immobile fraction. What is measured is the intensity of fluorescence and the time it takes to recover after photobleaching [31].
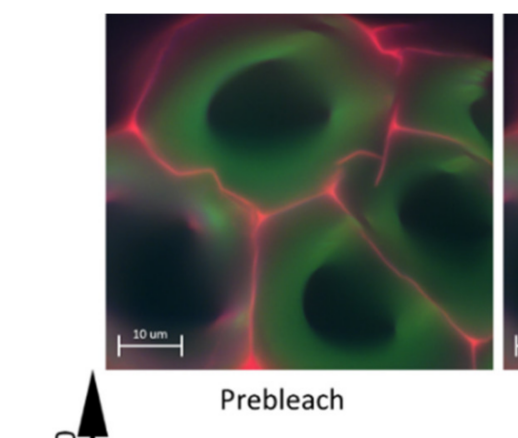

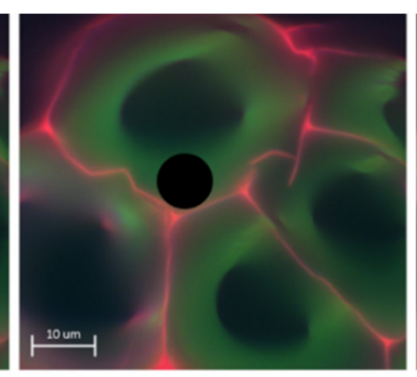

Bleaching
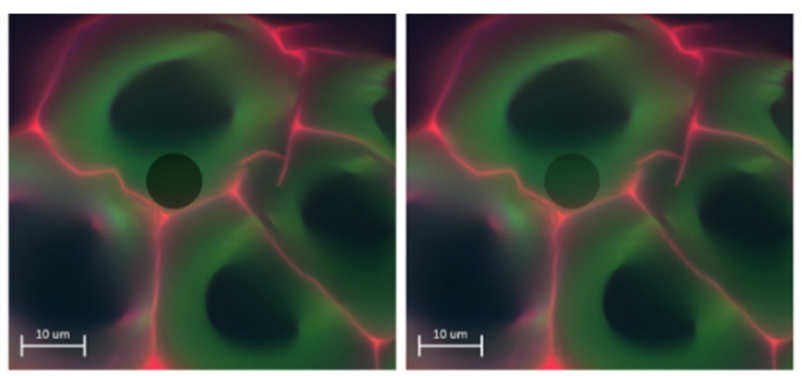

Fluorescence recovery after bleaching

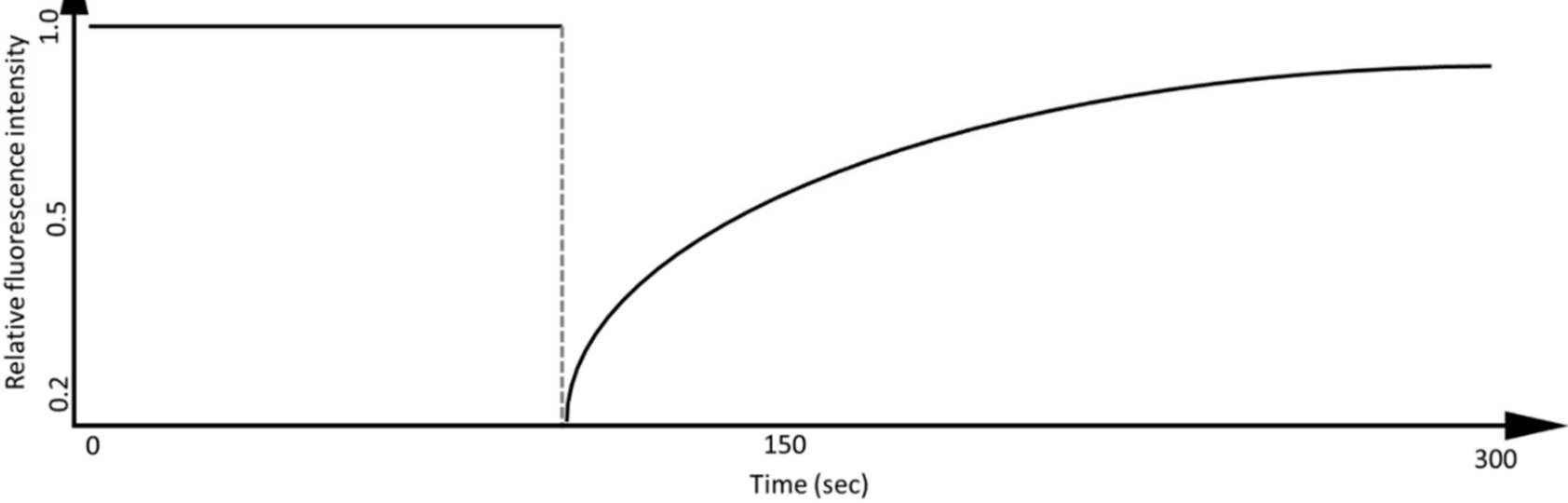

Figure 5. Schematic image of the FRAP method. Image taken from personal file, graphic based in [31].

Therefore, FRAP has been used to analyze the distribution of lignin-polymerizing enzymes, laccases, and peroxidases and to understand the roles they play in lignin polymerization and lignin distribution in the secondary and primary walls of vascular tissue [104]. In addition, with FRAP the diffusion of macromolecules in the cell wall can be identified [105] and test the diffusion of probes through gels, derived from grasses, that resemble the cellular structure [106]. Moreover, with FRAP, it was possible to determine the saccharification potential of the tissue of Populus nigra $\times$ deltoides [107] by analyzing mobility through their cell walls.

\subsection{Total Internal Reflection Fluorescence (TIRF)}

TIRF uses specific optics to produce illumination light only in the range of 50 to $100 \mathrm{~nm}$ at the interface [56], which drastically reduces the light from the bulb and improves the 
ability to detect fluorescent molecules only on the surface of the sample. TIRF uses the evanescent wave generated when the incident light undergoes total internal reflection or a highly inclined laminated optical sheet (HILO) to illuminate only a partial volume smaller than $200 \mathrm{~nm}$, obtaining the dynamic behavior of a single fluorescent molecule [65] unlike CLSM, which detects the fluorescence emission of the sample from the inner part of the sample. Due to better resolution images, TIRF can be used in conjunction with epifluorescence to characterize lignified fibers and cellular structures [108].

\subsection{Stimulated Emission Depletion (STED)}

STED is a super-resolution microscopy method based on confocal microscopy, in which images are acquired by scanning a point of light focused on a ROI, and fluorescence is collected sequentially pixel by pixel [109]. The system combines blue excitation lasers with red depletion lasers that pass through a phase plate to be patterned into a donut shape in the focal plane. The resulting excitation is a superposition of the two beams, leading to a highresolution probe scanning the sample, whereby the resulting effective detected fluorescence emission is collected with high spatial and axial resolutions on the nanometer scale, similar to what obtained with transmission electron microscopy (TEM) [110]. However, STED has some limitations because STED can easily damage fluorophores especially in living cells, the cost is high, and the quality may be affected due to red autofluorescence (such as the presence of chlorophyll) $[56,111]$.

The use of STED to characterize the distribution of lignin in plant tissues has been proposed by Päes et al. [109], who mentioned that the STED images to which a deconvolution process was applied show higher quality in regions such as the middle lamina and the secondary wall compared to CLSM. Based on these results, they suggest STED to detect changes in the degradation of wood by enzymatic action.

\section{Complementary Methods}

The methods mentioned above are accompanied by other methods that complement the information collected through fluorescence analysis. Qualitative methods based on transmission and scanning electron microscopy have made it possible to complement the ultrastructural analysis of the lignification of plant tissues $[52,76,112]$ in addition to allowing the characterization of lignocellulosic fibers based on their structure and shape [113,114]. As mentioned in section two, within brightfield microscopy, there are various histological techniques for lignin staining using dyes that can work for both brightfield and fluorescence microscopy, such as basic fuchsin [73] and safranin [62,115].

As for semi-quantitative analytical techniques, the most used in conjunction with CLSM is RAMAN spectroscopy, through which the inelastic dispersion of light is used, and the change in wavelength is detected, which is compiled to obtain information on the excited sample [116]. One of the advantages is that the analysis can be performed at the same time as CLSM in addition to the fact that it is not a destructive technique, and the material can be analyzed directly and without the need for preparation $[59,116]$. Other spectroscopic techniques are Fourier transform infrared spectroscopy (FTIR) [117] and near infrared spectroscopy (NIR) [118]. FTIR and NIR are based on the infrared absorption with which the molecular vibration of lignin is detected, so the purity of lignin or lignocellulosic materials can be calculated as well as quantifying approximate values of the S/G ratio of purified samples of lignin [15,115].

Within the quantitative techniques to analyze lignin, one of the most used is nuclear magnetic resonance spectroscopy (NMR spectroscopy). By t NMR spectroscopy, lignin of different species are structurally characterized by detecting protons in the structures $\left({ }^{1} \mathrm{H}\right.$ $\mathrm{NMR})$ or carbon isotopes $\left({ }^{13} \mathrm{C}-\mathrm{NMR}\right)$ and by using two-dimensional heteronuclear single quantum coherence (2D-HQC NMR) that combines the two previous methods and allows structural characterization of lignin [16,119]. Finally, other quantitative techniques less used in the characterization of lignin are chromatographic techniques, such as high-performance liquid chromatography (HPLC) [62,120]. A characteristic of the semiquantitative and 
quantitative methods mentioned in this section is that they are destructive methods and consume more time and resources. However, NMR spectroscopy and HPLC are necessary to confirm and justify the results obtained with most qualitative analyses, such as microscopy fluorescence.

\section{Conclusions and Future Perspectives}

As we can see in the Appendix A, the most-used method for the analysis of lignin is the CLSM in addition to being used in conjunction with the FLIM, FRET, TPM, and STED techniques; however, Epi in conjunction with FLIM, FRAP, and FRET techniques has been used. Most studies take advantage of the autofluorescence of lignin, and the dyes they use are mainly to dye cellulosic or hemicellulose structures because they do not emit autofluorescence, especially in the FRET method, where lignin and Rhodamine dye interact for the fluorescence emission. On the other hand, although the selected articles were the most recent, the FRET, FRAP, TPM FLIM, STED, and TIRF techniques have recently been applied to analyze the structure and composition of lignin. The data obtained can be semi-quantitative, and they allow comparisons to be made between the samples analyzed quickly, at low cost, and with non-destructive and super-resolution procedures as in the case of STED.

For this reason, with fluorescence microscopy techniques, lignin has been analyzed in a comprehensive manner so that not only the transport and polymerization process in the cell wall is identified, but lignin can also be characterized directly in the vascular or other plant tissues. In addition, the proportion of $S / G$ that allows identifying species with exploitation potential can be calculated, and lignocellulosic biomass can be analyzed to identify changes in its structure, derived from hydrolysis, pulping, and biopulping methods. Finally, although fluorescence microscopy methods are mainly qualitative and semi-quantitative, they are an efficient and rapid tool to characterize lignin.

Author Contributions: Writing-review and editing, A.M. and T.T., funding acquisition T.T. All authors have read and agreed to the published version of the manuscript.

Funding: Funding for this research was provided by Programa de Apoyo a Proyectos de Investigación e Innovación Tecnológica, Universidad Nacional Autónoma de México (PAPIIT-UNAM); grant no. IN205419 and IN212622 to TT.

Institutional Review Board Statement: Not applicable.

Informed Consent Statement: Not applicable.

Data Availability Statement: Not applicable.

Acknowledgments: Authors thank Elizabeth Navarro Cerón, LANISAF, for allowing the use of the Confocal Microscope, Lanabio (Biology Institute, UNAM) for allowing us to use the fluorescence microscope, and Verónica García Xicotencatl for artwork.

Conflicts of Interest: The authors declare no conflict of interest.

\section{Appendix A}

\begin{tabular}{ccccc}
\hline Method & Staining or Autofluorescence & Purpose & Species or Material Analyzed & Reference \\
\hline CLSM & BODIPY, ovalbumin with fluorescein & $\begin{array}{c}\text { Lignin peroxidase } \\
\text { effectiveness } \\
\text { Lignin transport and } \\
\text { polymerization }\end{array}$ & Lignin peroxidases \\
CLSM & $\begin{array}{c}\text { Autofluorescence, } \\
\text { monolignol fluorescence } \\
\text { CLSM }\end{array}$ & Monolignol fluorescence & Arabidopsis thaliana & [81-83] \\
\hline
\end{tabular}




\begin{tabular}{|c|c|c|c|c|}
\hline Method & Staining or Autofluorescence & Purpose & Species or Material Analyzed & Reference \\
\hline CLSM & $\begin{array}{c}\text { Autofluorescence, } \\
\text { monolignol fluorescence }\end{array}$ & Lignin polymerization & Linum usitatissimum & [86] \\
\hline CLSM & $\begin{array}{c}\text { Basic Fuchsin, Aramine O, Direct } \\
\text { Yellow } 96\end{array}$ & $\begin{array}{l}\text { Protocol for staining } \\
\text { cell walls }\end{array}$ & Arabidopsis thatiana & [73] \\
\hline CLSM & Basic Fuchsin & Lignin distribution & Brachypodium distachyon & [74] \\
\hline CLSM & Monolignol fluorescence & Lignin polymerization & Arabidopsis thaliana & [84] \\
\hline CLSM & Autofluorescence & Recalcitrant biomass & Miscanthus, poplar, wheat straw & [77] \\
\hline CLSM & Autofluorescence & Lignin distribution & Arabidopsis thaliana & {$[68]$} \\
\hline CLSM & Autofluorescence & $\begin{array}{l}\text { Protocol for lignin } \\
\text { fluorescence intensity }\end{array}$ & $\begin{array}{c}\text { Acacia melanoxylon, Eucalyptus } \\
\text { nitens, Pinus radiata, Populus } \\
\text { deltoides, P. heterophylla, Salix } \\
\text { chilensis, and S. nigra }\end{array}$ & [39] \\
\hline CLSM & Autofluorescence & $\begin{array}{l}\text { Wood characterization } \\
\text { and lignin distribution }\end{array}$ & Pinus radiata & [70] \\
\hline CLSM & Safranin & $\begin{array}{l}\text { Safranin staining } \\
\text { protocol and } \\
\text { lignin distribution }\end{array}$ & $\begin{array}{c}\text { Pinus radiata, Populus deltoides, } \\
\text { Pseudotsuga menziesii }\end{array}$ & [53] \\
\hline CLSM & Autofluorescence & Lignin concentration & $\begin{array}{c}\text { Arabidopsis thaliana, Linum } \\
\text { usitatissimum, Populus tremula } \times \\
\text { alba, Zea mays }\end{array}$ & [69] \\
\hline CLSM & Autofluorescence & $\begin{array}{l}\text { Presence of lignin in } \\
\text { cellulose nanofibers }\end{array}$ & Poplar powder & [75] \\
\hline CLSM & Autofluorescence, phloroglucinol & $\begin{array}{l}\text { Presence of fluorophores } \\
\text { in pine leaves }\end{array}$ & Pinus radiata needles & [41] \\
\hline CLSM & Autofluorescence & $\begin{array}{c}\text { Archaeological } \\
\text { wood degradation }\end{array}$ & Fir wood & [72] \\
\hline CLSM & p-HTEA solution & $\begin{array}{l}\text { New biomass } \\
\text { staining protocol }\end{array}$ & Lignocellulosic biomass & [71] \\
\hline CLSM & $\begin{array}{l}\text { Autofluorescence, monolignol } \\
\text { fluorescence }\end{array}$ & $\begin{array}{l}\text { Dual labeling protocol } \\
\text { for lignin }\end{array}$ & Linum usitatissimum & [83] \\
\hline CLSM & Autofluorescence & $\begin{array}{c}\text { Structural changes due to } \\
\text { heat treatments }\end{array}$ & Populus cathayana & [78] \\
\hline CLSM & $\begin{array}{c}\text { Basic Fuchsin, Aramine O, calcofluor } \\
\text { white }\end{array}$ & $\begin{array}{l}\text { Laccases lignin } \\
\text { polymerization }\end{array}$ & Arabidopsis thatiana & [87] \\
\hline $\begin{array}{l}\text { CLSM, } \\
\text { FLIM }\end{array}$ & Autofluorescence & $\begin{array}{l}\text { Comparison between } \\
\text { normal and } \\
\text { compression wood }\end{array}$ & Pinus radiata & [89] \\
\hline $\begin{array}{l}\text { CLSM, } \\
\text { FLIM }\end{array}$ & Autofluorescence & Lignin characterization & Arabidopsis thatiana & [90] \\
\hline $\begin{array}{l}\text { CLSM, } \\
\text { FLIM }\end{array}$ & Autofluorescence & $\begin{array}{l}\text { Presence of lignin in } \\
\text { cellulose nanofibers }\end{array}$ & Nanocellulose fibers & [38] \\
\hline $\begin{array}{l}\text { CLSM, } \\
\text { FLIM, Epi }\end{array}$ & Acridine orange & $\begin{array}{l}\text { Fungal oxidation } \\
\text { of wood }\end{array}$ & White spruce sapwood & [94] \\
\hline $\begin{array}{l}\text { CLSM, } \\
\text { FLIM, } \\
\text { FRET }\end{array}$ & Autofluorescence, Rhodamine B & $\begin{array}{l}\text { Saccharification } \\
\text { treatments }\end{array}$ & Pine, poplar coppice & [25] \\
\hline $\begin{array}{l}\text { CLSM, } \\
\text { FLIM, } \\
\text { TPM }\end{array}$ & Autofluorescence & $\begin{array}{l}\text { Saccharification } \\
\text { treatments }\end{array}$ & $\begin{array}{c}\text { Miscanthus } \times \text { giganteus, poplar, } \\
\text { wheat straw }\end{array}$ & {$[43]$} \\
\hline $\begin{array}{l}\text { CLSM, } \\
\text { FLIM, } \\
\text { TPM }\end{array}$ & Autofluorescence & $\begin{array}{l}\text { Alkaline and acid } \\
\text { treatments for lignin }\end{array}$ & $\begin{array}{l}\text { Eucalyptus fibers, } \\
\text { sugarcane bagasse }\end{array}$ & [92] \\
\hline $\begin{array}{l}\text { CLSM, } \\
\text { FLIM, } \\
\text { TPM }\end{array}$ & Autofluorescence & $\begin{array}{l}\text { Characterization of } \\
\text { lignocellulosic biomass }\end{array}$ & Sugarcane bagasse & [93] \\
\hline
\end{tabular}




\begin{tabular}{|c|c|c|c|c|}
\hline Method & Staining or Autofluorescence & Purpose & Species or Material Analyzed & Reference \\
\hline $\begin{array}{l}\text { CLSM, } \\
\text { FRAP }\end{array}$ & Autofluorescence, PEG-rhodamine & $\begin{array}{l}\text { Saccharification } \\
\text { treatments }\end{array}$ & Populus nigra $\times$ deltoides & [25] \\
\hline $\begin{array}{l}\text { CLSM, } \\
\text { FRAP }\end{array}$ & Autofluorescence and probes & $\begin{array}{l}\text { Diffusion of probes and } \\
\text { FRAP effectiveness }\end{array}$ & Feruloylated arabinoxylan gels & [106] \\
\hline $\begin{array}{l}\text { CLSM, } \\
\text { FRET }\end{array}$ & FITC, Rhodamine B & $\begin{array}{l}\text { Lignin nanoparticles } \\
\text { with peroxidases } \\
\text { and laccases }\end{array}$ & Lignin nanoparticles & [66] \\
\hline $\begin{array}{l}\text { CLSM, } \\
\text { FRET }\end{array}$ & Autofluorescence and PEG-rhodamine & $\begin{array}{l}\text { Interaction between PEG } \\
\text { and recalcitrant lignin }\end{array}$ & Pinus radiata & [67] \\
\hline $\begin{array}{l}\text { CLSM, } \\
\text { FRET }\end{array}$ & Autofluorescence and Congo red & Lignin recalcitrance & Pinus & [80] \\
\hline $\begin{array}{l}\text { CLSM, } \\
\text { FRET, } \\
\text { SLIM }\end{array}$ & Autofluorescence and Rhodamine B & Probe effectiveness & Wheat straw & [97] \\
\hline $\begin{array}{l}\text { CLSM, } \\
\text { STED }\end{array}$ & PEG-rhodamine (PEG-R) & Method Comparison & Poplar & [109] \\
\hline $\begin{array}{l}\text { CLSM, } \\
\text { TIRF, Epi }\end{array}$ & Calcofluor white & Fiber characterization & Agave fibers, garlic skin & [108] \\
\hline $\begin{array}{l}\text { CLSM, } \\
\text { TPM }\end{array}$ & Autofluorescence & Changes in wood & Spruce & {$[101]$} \\
\hline Epi & Autofluorescence, safranin & Lignin distribution & $\begin{array}{c}\text { Fraxinus ornus, Myrtus communis, } \\
\text { Olea europaea, Pistacia lentiscus, } \\
\text { Rhamnus alaternus }\end{array}$ & [36] \\
\hline Epi & Safranin/fast green & $\begin{array}{c}\text { Characterization of } \\
\text { secondary xylem lignin }\end{array}$ & 34 species of Cactaceae & [62] \\
\hline Epi & Safranin/fast green & $\begin{array}{l}\text { Characterization of } \\
\text { primary xylem lignin }\end{array}$ & 8 species of Cactaceae & [115] \\
\hline Epi & Autofluorescence & Lignin distribution & Pinus yunnanensis & [59] \\
\hline Epi & Modified Mäule staining & Staining protocol & Betula platyphylla & [61] \\
\hline Epi & Autofluorescence & $\begin{array}{c}\text { Structural changes due to } \\
\text { heat treatments }\end{array}$ & Fraxinus excelsior & [60] \\
\hline Epi & Safranin & $\begin{array}{l}\text { Fungal degradation } \\
\text { of wood }\end{array}$ & Eucalyptus grandis & [64] \\
\hline Epi & Acriflavine & $\begin{array}{l}\text { Lignocellulose } \\
\text { distribution }\end{array}$ & Cannabis sativa & [58] \\
\hline Epi, CLSM & $\begin{array}{l}\text { Autofluorescence, Filipin fluorescent } \\
\text { antibiotic reacting }\end{array}$ & Biopulping with fungus & Eucalyptus globulus & [76] \\
\hline Epi, CLSM & $\begin{array}{c}\text { Autofluorescence, Congo red, } \\
\text { Fluorol yellow }\end{array}$ & $\begin{array}{l}\text { Protocol for analyzing } \\
\text { cell walls }\end{array}$ & $\begin{array}{l}\text { Bruguiera gymnorrhiza, Picea } \\
\text { glauca, Pinus ponderosa, Populus } \\
\text { tremuloides, Rhizophora apiculata }\end{array}$ & [57] \\
\hline $\begin{array}{l}\text { Epi, FLIM, } \\
\text { TPM }\end{array}$ & Autofluorescence & $\begin{array}{l}\text { Biomass morphological } \\
\text { changes due to } \\
\text { hydrolysis }\end{array}$ & Corn stover & [55] \\
\hline Epi, FRAP & $\begin{array}{c}\text { Autofluorescence, m-CHERRY } \\
\text { red protein }\end{array}$ & Lignin polymerization & Arabidopsis & [104] \\
\hline Epi, FRET & Synthesized fluorochromes & Lignin polymerization & $\begin{array}{l}\text { Artificial lignified maize } \\
\text { cell walls }\end{array}$ & [44] \\
\hline FLIM & Autofluorescence & $\begin{array}{l}\text { Protocol to identify } \\
\text { timber species }\end{array}$ & $\begin{array}{c}\text { Beech, maple, spruce, and } \\
\text { walnut }\end{array}$ & [95] \\
\hline FLIM & Autofluorescence & Lignin composition & Arabidopsis thatiana & [96] \\
\hline TPM & Autofluorescence & $\begin{array}{l}\text { Structure analysis of } \\
\text { chitosan-lignin film }\end{array}$ & Chitosan-lignin composite film & [102] \\
\hline $\begin{array}{l}\text { TPM, } \\
\text { FRAP, } \\
\text { FRET, } \\
\text { sFLIM }\end{array}$ & Autofluorescence & $\begin{array}{l}\text { Protocol to analyze } \\
\text { biomass }\end{array}$ & Wheat straw & [103] \\
\hline
\end{tabular}




\section{References}

1. Renault, H.; Werck-Reichhart, D.; Weng, J.-K. Harnessing lignin evolution for biotechnological applications. Curr. Opin. Biotechnol. 2018, 56, 105-111. [CrossRef]

2. Liu, B.; Tang, L.; Chen, Q.; Zhu, L.; Zou, X.; Li, B.; Zhou, Q.; Fu, Y.; Lu, Y. Lignin Distribution on Cell Wall Micro-Morphological Regions of Fibre in Developmental Phyllostachys pubescens Culms. Polymers 2022, 14, 312. [CrossRef] [PubMed]

3. Sant'Anna, C.; Costa, L.T.; Abud, Y.; Biancatto, L.; Miguens, F.C.; de Souza, W. Sugarcane cell wall structure and lignin distribution investigated by confocal and electron microscopy. Microsc. Res. Tech. 2013, 76, 829-834. [CrossRef] [PubMed]

4. Marques, A.V.; Rencoret, J.; Gutiérrez, A.; del Río, J.C.; Pereira, H. Ferulates and lignin structural composition in cork. Holzforschung 2015, 70, 275-289. [CrossRef]

5. Goodell, B.; Winandy, J.E.; Morrell, J.J. Fungal Degradation of Wood: Emerging Data, New Insights and Charging Perceptions. Coatings 2020, 10, 1210. [CrossRef]

6. Chauve, M.; Barre, L.; Tapin-Lingua, S.; Perez, D.D.S.; Decottignies, D.; Perez, S.; Ferreira, N.L. Evolution and impact of cellulose architecture during enzymatic hydrolysis by fungal cellulases. Adv. Biosci. Biotechnol. 2013, 04, 1095-1109. [CrossRef]

7. Zhao, X.; Zhang, L.; Liu, D. Biomass recalcitrance. Part II: Fundamentals of different pre-treatments to increase the enzymatic digestibility of lignocellulose. Biofuels, Bioprod. Biorefining 2012, 6, 561-579. [CrossRef]

8. Singh, H.; Tomar, S.; Qureshi, K.A.; Jaremko, M.; Rai, P.K. Recent Advances in Biomass Pretreatment Technologies for Biohydrogen Production. Energies 2022, 15, 999. [CrossRef]

9. Zeng, Y.; Zhao, S.; Yang, S.; Ding, S.-Y. Lignin plays a negative role in the biochemical process for producing lignocellulosic biofuels. Curr. Opin. Biotechnol. 2014, 27, 38-45. [CrossRef]

10. Sekeri, S.H.; Ibrahim, M.N.M.; Umar, K.; Yaqoob, A.A.; Azmi, M.N.; Hussin, M.H.; Othman, M.B.H.; Malik, M.F.I.A. Preparation and characterization of nanosized lignin from oil palm (Elaeis guineensis) biomass as a novel emulsifying agent. Int. J. Biol. Macromol. 2020, 164, 3114-3124. [CrossRef]

11. Vena, P.F.; Görgens, J.F.; Rypstra, T. Hemicelluloses extraction from giant bamboo prior to Kraft and soda AQ pulping to produce paper pulps, value-added biopolymers and bioethanol. Cellul. Chem. Technol. 2010, 44, 153-163.

12. Megra, M.B.; Bachheti, R.K.; Tadesse, M.G.; Worku, L.A. Evaluation of Pulp and Papermaking Properties of Melia azedarach. Forests 2022, 13, 263. [CrossRef]

13. Ekpo, I.; Ogali, R.; Ofodile, S.; Achugasim, O. Comparison of biomass content for the evaluation of cellulosic ethanol fuel production from predominant perennial grasses in south-south. Nigeria Int. J. Appl. Sci. Technol. 2016, 6, 38-46.

14. Kumarasamy, R.; Uthandi, S.; Thangappan, S. Lignin Depolymerization Route Derived Commodities: Towards Tangible BioEconomy. Madras Agric. J. 2017, 104, 207. [CrossRef]

15. Maceda, A.; Soto-Hernández, M.; Peña-Valdivia, C.B.; Trejo, C.; Terrazas, T. Characterization of lignocellulose of Opuntia (Cactaceae) species using FTIR spectroscopy: Possible candidates for renewable raw material. Biomass Convers. Biorefinery 2020, 1-10. [CrossRef]

16. Reyes-Rivera, J.; Soto-Hernández, M.; Canché-Escamilla, G.; Terrazas, T. Structural Characterization of Lignin in Four Cacti Wood: Implications of Lignification in the Growth Form and Succulence. Front. Plant Sci. 2018, 9, 1518. [CrossRef]

17. Donaldson, L.A. Wood cell wall ultrastructure The key to understanding wood properties and behaviour. IAWA J. 2019, 40, 645-672. [CrossRef]

18. Saratale, R.G.; Saratale, G.D.; Ghodake, G.; Cho, S.-K.; Kadam, A.; Kumar, G.; Jeon, B.-H.; Pant, D.; Bhatnagar, A.; Shin, H.S Wheat straw extracted lignin in silver nanoparticles synthesis: Expanding its prophecy towards antineoplastic potency and hydrogen peroxide sensing ability. Int. J. Biol. Macromol. 2019, 128, 391-400. [CrossRef]

19. Saratale, R.G.; Cho, S.-K.; Saratale, G.D.; Kadam, A.A.; Ghodake, G.S.; Kumar, M.; Bharagava, R.N.; Kumar, G.; Kim, D.S.; Mulla, S.I.; et al. A comprehensive overview and recent advances on polyhydroxyalkanoates (PHA) production using various organic waste streams. Bioresour. Technol. 2021, 325, 124685. [CrossRef]

20. Welker, C.M.; Balasubramanian, V.K.; Petti, C.; Rai, K.M.; DeBolt, S.; Mendu, V. Engineering Plant Biomass Lignin Content and Composition for Biofuels and Bioproducts. Energies 2015, 8, 7654-7676. [CrossRef]

21. Studer, M.; DeMartini, J.D.; Davis, M.; Sykes, R.W.; Davison, B.; Keller, M.; Tuskan, G.; Wyman, C.E. Lignin content in natural Populus variants affects sugar release. Proc. Natl. Acad. Sci. USA 2011, 108, 6300-6305. [CrossRef] [PubMed]

22. Ralph, J.; Lundquist, K.; Brunow, G.; Lu, F.; Kim, H.; Schatz, P.F.; Marita, J.M.; Hatfield, R.D.; Ralph, S.A.; Christensen, J.H.; et al Lignins: Natural polymers from oxidative coupling of 4-hydroxyphenyl- propanoids. Phytochem. Rev. 2004, 3, 29-60. [CrossRef]

23. Wagner, A.; Tobimatsu, Y.; Phillips, L.; Flint, H.; Geddes, B.; Lu, F.; Ralph, J. Syringyl lignin production in conifers: Proof of concept in a Pine tracheary element system. Proc. Natl. Acad. Sci. USA 2015, 112, 6218-6223. [CrossRef] [PubMed]

24. Mottiar, Y.; Vanholme, R.; Boerjan, W.; Ralph, J.; Mansfield, S. Designer lignins: Harnessing the plasticity of lignification. Curr. Opin. Biotechnol. 2016, 37, 190-200. [CrossRef]

25. Chabbert, B.; Terryn, C.; Herbaut, M.; Vaidya, A.; Habrant, A.; Paës, G.; Donaldson, L. Fluorescence techniques can reveal cell wall organization and predict saccharification in pretreated wood biomass. Ind. Crop. Prod. 2018, 123, 84-92. [CrossRef]

26. Grabber, J.H. How Do Lignin Composition, Structure, and Cross-Linking Affect Degradability? A Review of Cell Wall Model Studies. Crop Sci. 2005, 45, 820-831. [CrossRef]

27. Lu, F.; Ralph, J. Lignin. In Cereal Straw as a Resource for Sustainable Biomaterials and Biofuels; Run-Cang, S., Ed.; Elsevier: Amsterdam, The Netherlands, 2010; pp. 169-207, ISBN 9780444532343. 
28. Chen, F.; Tobimatsu, Y.; Havkin-Frenkel, D.; Dixon, R.A.; Ralph, J. A polymer of caffeyl alcohol in plant seeds. Proc. Natl. Acad. Sci. USA 2012, 109, 1772-1777. [CrossRef]

29. Barceló, A.R.; Ros, L.G.; Gabaldón, C.; López-Serrano, M.; Pomar, F.; Carrión, J.; Pedreño, M. Basic peroxidases: The gateway for lignin evolution? Phytochem. Rev. 2004, 3, 61-78. [CrossRef]

30. Drummen, G.P.C. Fluorescent Probes and Fluorescence (Microscopy) Techniques-Illuminating Biological and Biomedical Research. Molecules 2012, 17, 14067-14090. [CrossRef]

31. Paës, G. Fluorescent Probes for Exploring Plant Cell Wall Deconstruction: A Review. Molecules 2014, 19, 9380-9402. [CrossRef]

32. Albinsson, B.; Li, S.; Lundquist, K.; Stomberg, R. The origin of lignin fluorescence. J. Mol. Struct. 1999, 508, 19-27. [CrossRef]

33. Donaldson, L.; Radotić, K.; Kalauzi, A.; Djikanović, D.; Jeremić, M. Quantification of compression wood severity in tracheids of Pinus radiata D. Don using confocal fluorescence imaging and spectral deconvolution. J. Struct. Biol. 2010, 169, 106-115. [CrossRef] [PubMed]

34. Machado, A.E.D.H.; De Paula, R.; Ruggiero, R.; Gardrat, C.; Castellan, A. Photophysics of dibenzodioxocins. J. Photochem. Photobiol. A Chem. 2006, 180, 165-174. [CrossRef]

35. Djikanović, D.; Kalauzi, A.; Radotić, K.; Lapierre, C.; Jeremić, M. Deconvolution of lignin fluorescence spectra: A contribution to the comparative structural studies of lignins. Russ. J. Phys. Chem. A 2007, 81, 1425-1428. [CrossRef]

36. Xue, Y.; Qiu, X.; Wu, Y.; Qian, Y.; Zhou, M.; Deng, Y.; Li, Y. Aggregation-induced emission: The origin of lignin fluorescence. Polym. Chem. 2016, 7, 3502-3508. [CrossRef]

37. Radotić, K.; Kalauzi, A.; Djikanović, D.; Jeremić, M.; Leblanc, R.M.; Cerović, Z.G. Component analysis of the fluorescence spectra of a lignin model compound. J. Photochem. Photobiol. B Biol. 2006, 83, 1-10. [CrossRef]

38. Patel, I.; Woodcock, J.; Beams, R.; Stranick, S.; Nieuwendaal, R.; Gilman, J.; Mulenos, M.; Sayes, C.; Salari, M.; DeLoid, G.; et al Fluorescently Labeled Cellulose Nanofibers for Environmental Health and Safety Studies. Nanomaterials 2021, 11, 1015. [CrossRef]

39. Donaldson, L. Softwood and Hardwood Lignin Fluorescence Spectra of Wood Cell Walls in Different Mounting Media. IAWA J. 2013, 34, 3-19. [CrossRef]

40. Donaldson, L. Autofluorescence in Plants. Molecules 2020, 25, 2393. [CrossRef]

41. Donaldson, L.; Williams, N. Imaging and Spectroscopy of Natural Fluorophores in Pine Needles. Plants 2018, 7, 10. [CrossRef]

42. Donaldson, L.A.; Knox, J.P. Localization of Cell Wall Polysaccharides in Normal and Compression Wood of Radiata Pine: Relationships with Lignification and Microfibril Orientation. Plant Physiol. 2011, 158, 642-653. [CrossRef] [PubMed]

43. Auxenfans, T.; Terryn, C.; Paës, G. Seeing biomass recalcitrance through fluorescence. Sci. Rep. 2017, 7, 8838. [CrossRef] [PubMed]

44. Tobimatsu, Y.; Davidson, C.L.; Grabber, J.H.; Ralph, J. Fluorescence-Tagged Monolignols: Synthesis, and Application to Studying In Vitro Lignification. Biomacromolecules 2011, 12, 1752-1761. [CrossRef]

45. Ma, Y.; Sawhney, V.; Steeves, T. Staining of paraffin-embedded plant material in safranin and fast green without prior removal of the paraffin. Can. J. Bot. 1993, 71, 996-999. [CrossRef]

46. Loza-Cornejo, S.; Terrazas, T. Anatomía del tallo y de la raíz de dos especies de Wilcoxia Britton \& Rose (Cactaceae) del noreste de México. Bot. Sci. 2017, 13-23. [CrossRef]

47. Kuroda, H.; Higuchi, T. O-Methyltransferase as a tool to evaluate the lignin evolution. Wood Res. 1982, 68, 53961233.

48. Pomar, F.; Merino, F.; Barceló, A.R. O -4-Linked coniferyl and sinapyl aldehydes in lignifying cell walls are the main targets of the Wiesner (phloroglucinol-HCl) reaction. Protoplasma 2002, 220, 17-28. [CrossRef]

49. Espiñeira, J.M.; Uzal, E.N.; Ros, L.V.G.; Carrión, J.S.; Merino, F.; Barceló, A.R.; Pomar, F. Distribution of lignin monomers and the evolution of lignification among lower plants. Plant Biol. 2010, 13, 59-68. [CrossRef]

50. Ros-Barceló, A.; Gómez-Ros, L.V.; Ferrer, M.A.; Hernandez, J.A. The apoplastic antioxidant enzymatic system in the wood-forming tissues of trees. Trees 2006, 20, 145-156. [CrossRef]

51. Brundrett, M.C.; Enstone, D.E.; Peterson, C.A. A berberine-aniline blue fluorescent staining procedure for suberin, lignin, and callose in plant tissue. Protoplasma 1988, 146, 133-142. [CrossRef]

52. Donaldson, L.A. Abnormal lignin distribution in wood from severely drought stressed pinus radiata trees. IAWA J. 2002, 23, 161-178. [CrossRef]

53. Bond, J.; Donaldson, L.; Hill, S.; Hitchcock, K. Safranine fluorescent staining of wood cell walls. Biotech. Histochem. 2008, 83, 161-171. [CrossRef] [PubMed]

54. Gray, J.D.; Kolesik, P.; Hoj, P.B.; Coombe, B.G. Confocal measurement of the three-dimensional size and shape of plant parenchyma cells in a developing fruit tissue. Plant J. 1999, 19, 229-236. [CrossRef] [PubMed]

55. Kapsokalyvas, D.; Loos, J.; Boogers, I.A.L.A.; Appeldoorn, M.M.; Kabel, M.; Van Zandvoort, M. Quantification of morphochemical changes during in situ enzymatic hydrolysis of individual biomass particles based on autofluorescence imaging. Biopolymers 2019, 111, e23347. [CrossRef] [PubMed]

56. DeVree, B.T.; Steiner, L.M.; Głazowska, S.; Ruhnow, F.; Herburger, K.; Persson, S.; Mravec, J. Current and future advances in fluorescence-based visualization of plant cell wall components and cell wall biosynthetic machineries. Biotechnol. Biofuels 2021, 14, 1-26. [CrossRef]

57. Kitin, P.; Nakaba, S.; Hunt, C.G.; Lim, S.; Funada, R. Direct fluorescence imaging of lignocellulosic and suberized cell walls in roots and stems. AoB Plants 2020, 12, plaa032. [CrossRef] [PubMed]

58. Kiyoto, S.; Yoshinaga, A.; Fernandez-Tendero, E.; Day, A.; Chabbert, B.; Takabe, K. Distribution of Lignin, Hemicellulose, and Arabinogalactan Protein in Hemp Phloem Fibers. Microsc. Microanal. 2018, 24, 442-452. [CrossRef] 
59. Ji, Z.; Ma, J.-F.; Zhang, Z.-H.; Xu, F.; Sun, R.-C. Distribution of lignin and cellulose in compression wood tracheids of Pinus yunnanensis determined by fluorescence microscopy and confocal Raman microscopy. Ind. Crop. Prod. 2013, 47, $212-217$. [CrossRef]

60. Kim, J.S.; Gao, J.; Terziev, N.; Cuccui, I.; Daniel, G. Chemical and ultrastructural changes of ash wood thermally modified using the thermo-vacuum process: I. Histo/cytochemical studies on changes in the structure and lignin chemistry. Holzforschung 2015, 69, 603-613. [CrossRef]

61. Yamashita, D.; Kimura, S.; Wada, M.; Takabe, K. Improved Mäule color reaction provides more detailed information on syringyl lignin distribution in hardwood. J. Wood Sci. 2016, 62, 131-137. [CrossRef]

62. Maceda, A.; Reyes-Rivera, J.; Soto-Hernández, M.; Terrazas, T. Distribution and Chemical Composition of Lignin in Secondary Xylem of Cactaceae. Chem. Biodivers. 2021, 18, e2100431. [CrossRef] [PubMed]

63. De Micco, V.; Aronne, G. Combined histochemistry and autofluorescence for identifying lignin distribution in cell walls. Biotech. Histochem. 2007, 82, 209-216. [CrossRef] [PubMed]

64. Benítez, V.; Franco, J.; Camargo, Á.; Raimonda, P.; Mantero, C.; Ibáñez, C.M. Influence of initial wood moisture on decay process by two brown-rot fungi. Maderas. Cienc. Tecnol. 2021, 23. [CrossRef]

65. Guo, A.-Y.; Zhang, Y.-M.; Wang, L.; Bai, D.; Xu, Y.-P.; Wu, W.-Q. Single-Molecule Imaging in Living Plant Cells: A Methodological Review. Int. J. Mol. Sci. 2021, 22, 5071. [CrossRef] [PubMed]

66. Capecchi, E.; Piccinino, D.; Tomaino, E.; Bizzarri, B.M.; Polli, F.; Antiochia, R.; Mazzei, F.; Saladino, R. Lignin nanoparticles are renewable and functional platforms for the concanavalin a oriented immobilization of glucose oxidase-peroxidase in cascade bio-sensing. RSC Adv. 2020, 10, 29031-29042. [CrossRef]

67. Donaldson, L.A.; Newman, R.H.; Vaidya, A. Nanoscale interactions of polyethylene glycol with thermo-mechanically pretreatedPinus radiatabiofuel substrate. Biotechnol. Bioeng. 2013, 111, 719-725. [CrossRef] [PubMed]

68. Decou, R.; Serk, H.; Ménard, D.; Pesquet, E. Analysis of Lignin Composition and Distribution Using Fluorescence Laser Confocal Microspectroscopy. Methods Mol. Biol. 2017, 1544, 233-247. [CrossRef]

69. Baldacci-Cresp, F.; Spriet, C.; Twyffels, L.; Blervacq, A.; Neutelings, G.; Baucher, M.; Hawkins, S. A rapid and quantitative safranin-based fluorescent microscopy method to evaluate cell wall lignification. Plant J. 2020, 102, 1074-1089. [CrossRef]

70. Donaldson, L.A.; Grace, J.; Downes, G.M. Within-tree variation in anatomical properties of compression wood in radiata pine. IAWA J. 2004, 25, 253-271. [CrossRef]

71. Choong, F.X.; Bäck, M.; Steiner, S.; Melican, K.; Nilsson, K.P.R.; Edlund, U.; Richter-Dahlfors, A. Nondestructive, real-time determination and visualization of cellulose, hemicellulose and lignin by luminescent oligothiophenes. Sci. Rep. 2016, 6, 35578. [CrossRef]

72. Huang, C.; Su, Y.; Shi, J.; Yuan, C.; Zhai, S.; Yong, Q. Revealing the effects of centuries of ageing on the chemical structural features of lignin in archaeological fir woods. New J. Chem. 2019, 43, 3520-3528. [CrossRef]

73. Ursache, R.; Andersen, T.G.; Marhavý, P.; Geldner, N. A protocol for combining fluorescent proteins with histological stains for diverse cell wall components. Plant J. 2017, 93, 399-412. [CrossRef] [PubMed]

74. Kapp, N.; Barnes, W.; Richard, T.; Anderson, C.T. Imaging with the fluorogenic dye Basic Fuchsin reveals subcellular patterning and ecotype variation of lignification in Brachypodium distachyon. J. Exp. Bot. 2015, 66, 4295-4304. [CrossRef] [PubMed]

75. Chen, Y.; Fan, D.; Han, Y.; Lyu, S.; Lu, Y.; Li, G.; Jiang, F.; Wang, S. Effect of high residual lignin on the properties of cellulose nanofibrils / films. Cellulose 2018, 25, 6421-6431. [CrossRef]

76. Speranza, M.; Gutiérrez, A.; Del Río, J.C.; Bettucci, L.; Martínez, A.T.; Martínez, M.J. Sterols and lignin in Eucalyptus globulus Labill. wood: Spatial distribution and fungal removal as revealed by microscopy and chemical analyses. Holzforschung 2009, 63, 362-370. [CrossRef]

77. Herbaut, M.; Zoghlami, A.; Habrant, A.; Falourd, X.; Foucat, L.; Chabbert, B.; Paës, G. Multimodal analysis of pretreated biomass species highlights generic markers of lignocellulose recalcitrance. Biotechnol. Biofuels 2018, 11, 52. [CrossRef]

78. Zhou, H.; Li, J.; Ma, E. Multiscale Modification of Populus cathayana by Alkali Lignin Combined with Heat Treatment. Polymers 2018, 10, 1240. [CrossRef]

79. Houtman, C.; Maligaspe, E.; Hunt, C.; Fernández-Fueyo, E.; Martínez, A.T.; Hammel, K.E. Fungal lignin peroxidase does not produce the veratryl alcohol cation radical as a diffusible ligninolytic oxidant. J. Biol. Chem. 2018, 293, 4702-4712. [CrossRef]

80. Donaldson, L.; Vaidya, A. Visualising recalcitrance by colocalisation of cellulase, lignin and cellulose in pretreated pine biomass using fluorescence microscopy. Sci. Rep. 2017, 7, 44386. [CrossRef]

81. Bukowski, N.; Pandey, J.L.; Doyle, L.; Richard, T.L.; Anderson, C.T.; Zhu, Y. Development of a Clickable Designer Monolignol for Interrogation of Lignification in Plant Cell Walls. Bioconjugate Chem. 2014, 25, 2189-2196. [CrossRef]

82. Pandey, J.L.; Wang, B.; Diehl, B.G.; Richard, T.; Chen, G.; Anderson, C.T. A Versatile Click-Compatible Monolignol Probe to Study Lignin Deposition in Plant Cell Walls. PLoS ONE 2015, 10, e121334. [CrossRef] [PubMed]

83. Simon, C.; Lion, C.; Spriet, C.; Baldacci-Cresp, F.; Hawkins, S.; Biot, C. One, Two, Three: A Bioorthogonal Triple Labelling Strategy for Studying the Dynamics of Plant Cell Wall Formation In Vivo. Angew. Chem. Int. Ed. 2018, 57, 16665-16671. [CrossRef] [PubMed]

84. Tobimatsu, Y.; Schuetz, M. Lignin polymerization: How do plants manage the chemistry so well? Curr. Opin. Biotechnol. 2018, 56, 75-81. [CrossRef] [PubMed] 
85. Tobimatsu, Y.; Wagner, A.; Donaldson, L.; Mitra, P.; Niculaes, C.; Dima, O.; Kim, J.I.; Anderson, N.; Loque, D.; Boerjan, W.; et al. Visualization of plant cell wall lignification using fluorescence-tagged monolignols. Plant J. 2013, 76, 357-366. [CrossRef] [PubMed]

86. Lion, C.; Simon, C.; Huss, B.; Blervacq, A.-S.; Tirot, L.; Toybou, D.; Spriet, C.; Slomianny, C.; Guerardel, Y.; Hawkins, S.; et al. BLISS: A Bioorthogonal Dual-Labeling Strategy to Unravel Lignification Dynamics in Plants. Cell Chem. Biol. 2017, $24,326-338$. [CrossRef] [PubMed]

87. Zhuang, Y.; Zuo, D.; Tao, Y.; Cai, H.; Li, L. Laccase3-based extracellular domain provides possible positional information for directing Casparian strip formation inArabidopsis. Proc. Natl. Acad. Sci. USA 2020, 117, 15400-15402. [CrossRef]

88. Simon, C.; Spriet, C.; Hawkins, S.; Lion, C. Visualizing Lignification Dynamics in Plants with Click Chemistry: Dual Labeling is BLISS! J. Vis. Exp. 2018, e56947. [CrossRef]

89. Donaldson, L.; Radotic, K. Fluorescence lifetime imaging of lignin autofluorescence in normal and compression wood. J. Microsc. 2013, 251, 178-187. [CrossRef]

90. Wightman, R.; Busse-Wicher, M.; Dupree, P. Correlative FLIM-confocal-Raman mapping applied to plant lignin composition and autofluorescence. Micron 2019, 126, 102733. [CrossRef]

91. Berezin, M.Y.; Achilefu, S. Fluorescence Lifetime Measurements and Biological Imaging. Chem. Rev. 2010, 110, 2641-2684. [CrossRef]

92. Coletta, V.C.; Rezende, C.A.; da Conceição, F.R.; Polikarpov, I.; Guimarães, F.E.G. Mapping the lignin distribution in pretreated sugarcane bagasse by confocal and fluorescence lifetime imaging microscopy. Biotechnol. Biofuels 2013, 6, 43. [CrossRef] [PubMed]

93. Chimenez, T.A.; Gehlen, M.H.; Marabezi, K.; Curvelo, A.A.S. Characterization of sugarcane bagasse by autofluorescence microscopy. Cellulose 2013, 21, 653-664. [CrossRef]

94. Houtman, C.; Kitin, P.; Houtman, J.; Hammel, K.E.; Hunt, C. Acridine Orange Indicates Early Oxidation of Wood Cell Walls by Fungi. PLoS ONE 2016, 11, e0159715. [CrossRef]

95. Leiter, N.; Wohlschläger, M.; Auer, V.; Versen, M.; Laforsch, C. B10.2 A Novel Approach to Identify Wood Species Optically Using Fluorescence Lifetime Imaging Microscopy; AMA: Berlin, Germany, 2021; pp. 169-170. [CrossRef]

96. Escamez, S.; Terryn, C.; Gandla, M.L.; Yassin, Z.; Scheepers, G.; Näsholm, T.; Sundman, O.; Jönsson, L.J.; Lundberg-Felten, J.; Tuominen, H.; et al. Fluorescence Lifetime Imaging as an In Situ and Label-Free Readout for the Chemical Composition of Lignin. ACS Sustain. Chem. Eng. 2021. [CrossRef]

97. Terryn, C.; Paës, G.; Spriet, C. FRET-SLiM on native autofluorescence: A fast and reliable method to study interactions between fluorescent probes and lignin in plant cell wall. Plant Methods 2018, 14, 74. [CrossRef]

98. Benninger, R.; Piston, D.W. Two-Photon Excitation Microscopy for the Study of Living Cells and Tissues. Curr. Protoc. Cell Biol. 2013, 59, 4.11.1-4.11.24. [CrossRef]

99. Nadiarnykh, O.; LaComb, R.B.; Campagnola, P.J.; Mohler, W.A. Coherent and incoherent SHG in fibrillar cellulose matrices. Opt. Express 2007, 15, 3348-3360. [CrossRef]

100. Peciulyte, A.; Kiskis, J.; Larsson, P.T.; Olsson, L.; Enejder, A. Visualization of structural changes in cellulosic substrates during enzymatic hydrolysis using multimodal nonlinear microscopy. Cellulose 2016, 23, 1521-1536. [CrossRef]

101. Tai, H.-C.; Chen, P.-L.; Xu, J.-W.; Chen, S.-Y. Two-photon fluorescence and second harmonic generation hyperspectral imaging of old and modern spruce woods. Opt. Express 2020, 28, 38831-38841. [CrossRef]

102. Crouvisier-Urion, K.; Lagorce-Tachon, A.; Lauquin, C.; Winckler, P.; Tongdeesoontorn, W.; Domenek, S.; Debeaufort, F.; Karbowiak, T. Impact of the homogenization process on the structure and antioxidant properties of chitosan-lignin composite films. Food Chem. 2017, 236, 120-126. [CrossRef] [PubMed]

103. Terryn, C.; Habrant, A.; Paës, G.; Spriet, C. Measuring Interactions between Fluorescent Probes and Lignin in Plant Sections by sFLIM Based on Native Autofluorescence. J. Vis. Exp. 2020, e59925. [CrossRef] [PubMed]

104. Chou, E.Y.; Schuetz, M.; Hoffmann, N.; Watanabe, Y.; Sibout, R.; Samuels, A.L. Distribution, mobility, and anchoring of lignin-related oxidative enzymes in Arabidopsis secondary cell walls. J. Exp. Bot. 2018, 69, 1849-1859. [CrossRef] [PubMed]

105. Kvist, P.; Schuster, E.; Lorén, N.; Rasmuson, A. Using fluorescent probes and FRAP to investigate macromolecule diffusion in steam-exploded wood. Wood Sci. Technol. 2018, 52, 1395-1410. [CrossRef]

106. Paës, G.; Chabbert, B. Characterization of Arabinoxylan/Cellulose Nanocrystals Gels to Investigate Fluorescent Probes Mobility in Bioinspired Models of Plant Secondary Cell Wall. Biomacromolecules 2011, 13, 206-214. [CrossRef]

107. Herbaut, M.; Zoghlami, A.; Paës, G. Dynamical assessment of fluorescent probes mobility in poplar cell walls reveals nanopores govern saccharification. Biotechnol. Biofuels 2018, 11, 271. [CrossRef]

108. Hernández-Varela, J.; Chanona-Pérez, J.; Benavides, H.C.; Cerda, S.G.; Victoriano, L.G.; Flores, M.D.J.P.; López, M.C.; Candelas, L.E.R.; Tamato, B.A. CLSM and TIRF images from lignocellulosic materials: Garlic skin and agave fibers study. Microsc. Microanal. 2021, 27, 1730-1734. [CrossRef]

109. Paës, G.; Habrant, A.; Terryn, C. Fluorescent Nano-Probes to Image Plant Cell Walls by Super-Resolution STED Microscopy. Plants 2018, 7, 11. [CrossRef]

110. Blom, H.; Brismar, H. STED microscopy: Increased resolution for medical research? J. Intern. Med. 2014, 276, 560-578. [CrossRef]

111. Schubert, V. Super-resolution Microscopy-Applications in Plant Cell Research. Front. Plant Sci. 2017, 8. [CrossRef]

112. Donaldson, L.A. Lignification and lignin topochemistry-An ultrastructural view. Phytochemistry 2001, 57, 859-873. [CrossRef] 
113. Menezes, F.; Rocha, G.; Maciel Filho, R. Obtainment and characterization of lignin from enzymatic hydrolysis of sugarcane bagasse of e2g process in pilot scale. Chem. Eng. Trans. 2016, 50, 397-402. [CrossRef]

114. Cabrales, L.; Abidi, N.; Manciu, F. Characterization of Developing Cotton Fibers by Confocal Raman Microscopy. Fibers 2014, 2, 285-294. [CrossRef]

115. Maceda, A.; Soto-Hernández, M.; Peña-Valdivia, C.B.; Trejo, C.; Terrazas, T. Differences in the Structural Chemical Composition of the Primary Xylem of Cactaceae: A Topochemical Perspective. Front. Plant Sci. 2019, 10, 1497. [CrossRef] [PubMed]

116. Vítek, P.; Klem, K.; Urban, O. Application of Raman spectroscopy to analyse lignin/cellulose ratio in Norway spruce tree rings. Beskydy 2017, 10, 41-48. [CrossRef]

117. Rashid, T.; Kait, C.F.; Murugesan, T. A “Fourier Transformed Infrared” Compound Study of Lignin Recovered from a Formic Acid Process. Procedia Eng. 2016, 148, 1312-1319. [CrossRef]

118. Ai, N.; Jiang, Y.; Omar, S.; Wang, J.; Xia, L.; Ren, J. Rapid Measurement of Cellulose, Hemicellulose, and Lignin Content in Sargassum horneri by Near-Infrared Spectroscopy and Characteristic Variables Selection Methods. Molecules 2022, $27,335$. [CrossRef]

119. Wen, J.-L.; Sun, S.-L.; Xue, B.-L.; Sun, R.-C. Recent Advances in Characterization of Lignin Polymer by Solution-State Nuclear Magnetic Resonance (NMR) Methodology. Materials 2013, 6, 359-391. [CrossRef]

120. Reyes-Rivera, J.; Canché-Escamilla, G.; Soto-Hernandez, M.; Terrazas, T. Wood Chemical Composition in Species of Cactaceae: The Relationship between Lignification and Stem Morphology. PLoS ONE 2015, 10, e0123919. [CrossRef] 